\title{
Influence of clonidine induced sympathicolysis on anaemia tolerance in anaesthetized pigs
}

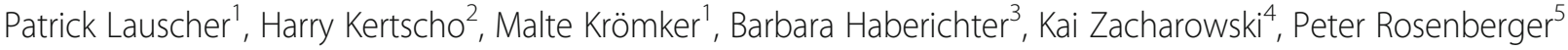 \\ and Jens Meier ${ }^{\sigma^{*}}$
}

\begin{abstract}
Background: Clonidine effectively decreases perioperative mortality by reducing sympathetic tone. However, application of clonidine might also restrict anaemia tolerance due to impairment of compensatory mechanisms. Therefore, the influence of clonidine induced, short-term sympathicolysis on anaemia tolerance was assessed in anaesthetized pigs. We measured the effect of clonidine on anaemia tolerance and of the potential for macrohemodynamic alterations to constrain the acute anaemia compensatory mechanisms.

Methods: After governmental approval, 14 anaesthetized pigs of either gender (Deutsche Landrasse, weight (mean \pm SD) $24.1 \pm 2.4 \mathrm{~kg}$ ) were randomly assigned to intravenous saline or clonidine treatment (bolus: $20 \mathrm{\mu g} \cdot \mathrm{kg}^{-1}$, continuous infusion: $15 \mathrm{\mu g} \cdot \mathrm{kg}^{-1} \cdot \mathrm{h}^{-1}$ ). Thereafter, the animals were hemodiluted by exchange of whole blood for $6 \%$ hydroxyethyl starch (MW 130.000/0.4) until the individual critical haemoglobin concentration ( $\mathrm{Hb}_{\text {crit }}$ ) was reached. Primary outcome parameters were $\mathrm{Hb}_{\text {crit }}$ and the exchangeable blood volume (EBV) until $\mathrm{Hb}_{\text {crit }}$ was reached.

Results: $\mathrm{Hb}_{\text {crit }}$ did not differ between both groups (values are median [interquartile range]: saline: $2.2(2.0-2.5) \mathrm{g} \cdot \mathrm{dL}^{-1}$ vs. clonidine: $2.1(2.1-2.4) \mathrm{g} \cdot \mathrm{dL}^{-1}$; n.s.). Furthermore, there was no difference in exchangeable blood volume (EBV) between both groups (saline: $88(76-106) \mathrm{mL} \cdot \mathrm{kg}^{-1}$ vs. clonidine: $92(85-95) \mathrm{mL} \cdot \mathrm{kg}^{-1}$; n.s.).

Conclusion: Anaemia tolerance was not affected by clonidine induced sympathicolysis. Consequently, perioperative clonidine administration probably has not to be omitted in view of acute anaemia.
\end{abstract}

Keywords: Anaemia, Hemodilution, Critical haematocrit, Oxygen consumption, Clonidine, Sympathicolysis

\section{Background}

Allogeneic blood transfusions are expensive and, though safer than ever before, are still associated with potential infectious, immunologic, and immunosuppressive risks.

Therefore one pillar of modern patient blood management concepts is to decrease the number of perioperative blood transfusions by accepting low intraoperative haemoglobin concentrations without endangering tissue oxygenation. However, this decline of oxygen carrying capacity has to be compensated for by an increase of cardiac output, organ perfusion, and oxygen extraction ratio [1-3]. As long as these compensatory mechanisms

\footnotetext{
* Correspondence: jens.meier@akh.linz.at

${ }^{6}$ Department of Anesthesia and Intensive Care, Faculty of Medicine of the Kepler University Linz, 4021 Linz, Austria

Full list of author information is available at the end of the article
}

can be utilized, remarkable degrees of anaemia can be survived, and less severe anaemia can be sustained without significant sequelae [4].

Presently, a considerable number of patients are treated with perioperative $\alpha_{2}$-agonists, either for sympathicolysis to reduce perioperative cardiac risk or for sedation during ICU hospitalization [5]. Perioperative $\alpha_{2}$-adrenergic agonists decrease global oxygen consumption [6] and improve perioperative myocardial morbidity and mortality $[7,8]$ by increasing coronary perfusion especially in ischemic heart disease [9], by improving coronary reserve, and by decreasing oxygen consumption $[6,10]$. Furthermore, they are widely used for postoperative sedation in the ICU [11].

However, the influence of clonidine induced cardiovascular alterations on acute anaemia tolerance is currently unknown. Therefore we determined the effect of clonidine 
on anaemia tolerance and haemodynamic compensatory mechanisms of acute anaemia in a pig model of acute normovolemic hemodilution.

\section{Methods}

The experimental protocol was approved by the Animal Care Committee (Regierungspräsidium Darmstadt, Hessen, F 143/18). The experiments were performed in 14 pigs (Deutsche Landrasse) of either sex (mean body weight $24.1 \pm 2.4 \mathrm{~kg}$ ). The animals were treated in accordance with the Principles of Laboratory Animal Care (National Institute of Health publications 86-23, 1985).

\section{Anaesthesia}

Food was withheld one night prior to anaesthesia, but animals had free access to water. Midazolam $\left(1.5 \mathrm{mg} \cdot \mathrm{kg}^{-1}\right)$ and ketamine $\left(10 \mathrm{mg} \cdot \mathrm{kg}^{-1}\right)$ were administered intramuscularly prior to anaesthesia. Anaesthesia was induced with intravenous fentanyl $\left(0.01 \mathrm{mg} \cdot \mathrm{kg}^{-1}\right)$, propofol $(2 \mathrm{mg} \cdot \mathrm{kg}$ $\left.{ }^{-1}\right)$, and vecuronium bromide $\left(0.3 \mathrm{mg} \cdot \mathrm{kg}^{-1}\right)$ and maintained by continuous intravenous fentanyl $(0.045 \mathrm{mg} \cdot \mathrm{kg}$ $\left.{ }^{-1} \cdot \mathrm{h}^{-1}\right)$, propofol $\left(10 \mathrm{mg} \cdot \mathrm{kg}^{-1} \cdot \mathrm{h}^{-1}\right)$, and midazolam (0.6 $\mathrm{mg} \cdot \mathrm{kg}^{-1} \cdot \mathrm{h}^{-1}$ ) infusion. Vecuronium bromide $\left(1.0 \mathrm{mg} \cdot \mathrm{kg}^{-1} \cdot \mathrm{h}^{-1}\right.$ ) was administered continuously to maintain muscular relaxation and minimize muscular oxygen consumption. Estimated insensitive fluid losses were compensated for by intravenous administration of isotonic electrolyte solution $\left(3 \mathrm{~mL}^{-1} \cdot \mathrm{kg}^{-1} \cdot \mathrm{h}^{-1}\right.$; Sterofun$\operatorname{din}^{\circ}$ ISO, B. Braun Melsungen AG, Melsungen, Germany).

A warming blanket (Warm Touch, Mallinckrodt/Convidien; Boulder, CO, USA) was used to maintain constant body temperature (baseline temperature $\pm 0.25{ }^{\circ} \mathrm{C}$ ). Animals were intubated endotracheally and mechanically ventilated $\left(\mathrm{FiO}_{2}\right.$ 0.21) at a rate of $12-15 \mathrm{~min}^{-1}$ and a positive end-expiratory pressure of $5 \mathrm{cmH}_{2} \mathrm{O}$. The minute volume was adjusted to maintain normocapnia, which was confirmed by multiple blood gas analyses.

\section{Instrumentation and monitoring}

All animals were placed in supine position. A 12-lead electrocardiogram was recorded continuously during the entire experiment. Several intravascular catheters were placed using Seldinger's technique to avoid stress related to surgical preparation. A Picco thermodilution catheter (PICCO Pulsiocath, PULSION Medical Systems AG, Munich, Germany) was placed in the right femoral artery to measure arterial pressure and continuously measure cardiac output.

A 20-gauge catheter was placed in the left femoral artery for phlebotomy, and a 16-gauge catheter inserted into a femoral vein to administer hydroxyethyl starch during hemodilution. A 16-gauge catheter was inserted through the left external jugular vein into the upper vena cava to administer anaesthetic agents and monitor central venous pressure; a pulmonary arterial catheter (7.5 Fr, Edwards Swan-Ganz, Baxter Healthcare, Irvine, CA) was inserted to sample mixed venous blood and monitor pulmonary arterial pressure. The catheter positions were verified by blood gas analysis and radiography.

\section{Experimental protocol}

After instrumentation, a 60 -min stabilization period was allowed for $\mathrm{VO}_{2}$ stabilization (see: Determination of Hbcrit) before the first set of data was collected (baseline, BL1). Blood volume was determined by indocyanine green dilution kinetics using the "whole blood method"[12]. The animals were then randomized into two experimental groups comprising seven animals each.

After randomization animals received either $20 \mu \mathrm{g} \cdot \mathrm{kg}^{-1}$ clonidine over a 10 -min period (clonidine group) or an equal volume of saline (control group) according to randomization. Thereafter, $15 \mu \mathrm{g} \cdot \mathrm{kg}^{-1} \cdot \mathrm{h}^{-1}$ clonidine or the equal amount of saline was administered intravenously. After the initial bolus, a 60 -min stabilization period elapsed, and a second set of data set was collected (BL2).

After baseline 2 (BL2) all animals were hemodiluted isovolemically with HES $6 \%$ (MW 130.000/0.4) at an exchange rate of $1 \mathrm{~mL} \cdot \mathrm{kg}^{-1} \cdot \mathrm{min}^{-1}$ with a infuse/withdrawal dual syringe pump (Harvard Apparatus, Holliston, MA, US) until the critical haemoglobin concentration $\left(H b_{\text {crit }}\right)$ was reached. The hemodilution procedure was performed in steps of $200 \mathrm{ml}$, after which a short break for hemodynamic measurements took place. This procedure was repeated until the critical haemoglobin concentration (time point $\mathrm{Hb}_{\text {crit }}$ ) was detected. $\mathrm{Hb}_{\text {crit }}$ was defined as a significant decrease in total body $\mathrm{VO}_{2}$ compared to the baseline value (see: Determination of Hbcrit). The total blood volume that was exchanged to reach $\mathrm{Hb}_{\text {crit }}$ was designated as the exchangeable blood volume (EBV).

\section{Measurements}

Arterial and mixed venous $\mathrm{PO}_{2}$ and $\mathrm{PCO}_{2}, \mathrm{pH}$, electrolytes, haematocrit and arterial serum lactate concentration was measured using a blood analysing system (Premier GEM 3000, Instrumentation Laboratory, Lexington, MA, USA). Haemoglobin concentration $(\mathrm{Hb})$ and arterial haemoglobin-oxygen saturation $\left(\mathrm{SaO}_{2}\right)$ were measured by spectrophotometry adjusted to swine haemoglobin (682 CO-Oximeter, Instrumentation Laboratory, Lexington, MA, USA). Oxygen transport and uptake were calculated as described in the Appendix.

\section{Data analysis}

Six experimental data sets were used for calculations, defined as the baseline measurement (BL1), after clonidine medication (second baseline, after medication, BL2) and when $25,50,75$, and $100 \%$ of exchangeable blood volume 
(EBV) until $\mathrm{Hb}_{\text {crit }}$ were exchanged. These parameters are summarized in Table 2.

The main outcome parameter of the study was the critical haemoglobin concentration $\left(\mathrm{Hb}_{\text {crit }}\right)$ and the exchangeable blood volume (EBV) until $\mathrm{Hb}_{\text {crit }}$ was reached. Secondary outcome parameters were several macrohemodynamic, oxygen transport, and tissue oxygenation parameters.

\section{Determination of $\mathrm{Hb}_{\text {crit }}$}

In steady state, tissue oxygen consumption $\left(\mathrm{VO}_{2}\right)$ equals oxygen demand. However, when $\mathrm{DO}_{2}$ decreases (e.g. by hemodilution) below a critical value, $\mathrm{VO}_{2}$ becomes oxygen supply-dependent and decreases (Table 1, Fig. 1a). This sudden $\mathrm{VO}_{2}$ decrease reflects the onset of global tissue hypoxia [13], and the corresponding haemoglobin concentration is called the "critical" $\mathrm{Hb}$ concentration $\left(\mathrm{Hb}_{\text {crit }}\right)$. Previous studies found that $100 \%$ of animals died within $3 \mathrm{~h}$ after achieving $\mathrm{Hb}_{\text {crit }}[14]$.

Total body $\mathrm{VO}_{2}$ was measured non-invasively at 1-min intervals using a DeltaTrac metabolic monitor (DeltaTrac IITM MBM-200, Datex, Helsinki, Finland) connected to the ventilator. $\mathrm{Hb}_{\text {crit }}$ was automatically detected using computer software especially designed for this purpose (DeltaCrit System) [15]. $\mathrm{VO}_{2}$ values collected during the

Table 1 Macrohemodynamics

\begin{tabular}{|c|c|c|c|c|c|c|c|}
\hline & Group & $\mathrm{BL} 1$ & BL2 & $25 \%$ & $50 \%$ & $75 \%$ & $\mathrm{Hb}_{\text {crit }}$ \\
\hline$H R$ & Saline & $88(87-107)$ & $84(83-107)^{* *}$ & $91(84-109)^{* *}$ & $107(85-113)$ & $128(95-132)$ & $130(98-142)^{* *}$ \\
\hline bpm & Clonidine & $88(79-114)$ & $57(53-62)^{* *}$ & $64(63-76)^{* *}$ & $83(79-88)$ & $96(91-116)$ & $95(94-101)^{* *}$ \\
\hline MAP & Saline & $88(69-107)$ & $87(70-105)^{* *}$ & 87 (69-99) & $87(70-96)$ & $80(64-93)$ & $53(48-59)$ \\
\hline $\mathrm{mmHg}$ & Clonidine & $85(75-90)$ & $113(104-124)^{* *}$ & 91 (83-99) & $85(79-88)$ & $67(66-79)$ & $46(27-52)$ \\
\hline $\mathrm{Cl}$ & Saline & $5,9(5,4-6,3)$ & $6,0(5,6-6,3)^{* *}$ & $6,1(5,4-6,9)^{* *}$ & $6,9(6,5-8,1)^{* *}$ & $7,3(7,0-8,5)$ & $7,9(7,4-8,5)$ \\
\hline$L \min ^{-1} \mathrm{~m}^{-2}$ & Clonidine & $5,3(4,6-5,6)$ & $2,4(2,2-3,4)^{* *}$ & $4,0(3,5-4,6)^{* *}$ & $5,1(4,3-5,7)^{* *}$ & $6,5(5,7-7,7)$ & $6,9(6,0-8,5)$ \\
\hline SVRI & Saline & $\begin{array}{l}2216 \\
(1755-2404)\end{array}$ & $\begin{array}{l}2150 \\
(1656-2391)^{* *}\end{array}$ & $\begin{array}{l}1791 \\
(1509-2072)^{* *}\end{array}$ & $\begin{array}{l}1500 \\
(1321-1739)\end{array}$ & $\begin{array}{l}1526 \\
(989-1547)\end{array}$ & $\begin{array}{l}677 \\
(624-830)\end{array}$ \\
\hline dyn $\sec \mathrm{cm}^{-5} \mathrm{~m}^{-2}$ & Clonidine & $\begin{array}{l}2646 \\
(1997-3196)\end{array}$ & $\begin{array}{l}4812 \\
(4649-5471)^{* *}\end{array}$ & $\begin{array}{l}2678 \\
(2077-3203)^{* *}\end{array}$ & $\begin{array}{l}1980 \\
(1736-2102)\end{array}$ & $\begin{array}{l}1247 \\
(1171-1492)\end{array}$ & $\begin{array}{l}428 \\
(354-559)\end{array}$ \\
\hline PVRI & Saline & $281(276-332)$ & $317(284-361)$ & $224(205-308)$ & 209 (194-221) & 205 (190-264) & $162(135-173)$ \\
\hline dyn sec $\mathrm{cm}^{-5} \mathrm{~m}^{-2}$ & Clonidine & $316(262-389)$ & $379(327-457)$ & $271(248-360)$ & $278(262-285)$ & $231(225-248)$ & $139(123-177)$ \\
\hline CPP & Saline & $62(43-71)$ & $60(46-70)^{* *}$ & $51(41-63)$ & $41(37-61)$ & $32(32-58)$ & $23(13-27)$ \\
\hline $\mathrm{mmHg}$ & Clonidine & $49(43-62)$ & $77(71-84)^{* *}$ & $53(47-61)$ & $46(37-53)$ & $35(25-40)$ & $6(2-16)$ \\
\hline LVPsys & Saline & $121(85-127)$ & $122(86-126)^{* *}$ & $109(87-121)^{* *}$ & $102(85-115)$ & $95(82-113)$ & $77(74-80)$ \\
\hline $\mathrm{mmHg}$ & Clonidine & 105 (101-113) & $143(138-157)^{* *}$ & $121(117-130)^{* *}$ & $114(106-119)$ & $100(90-108)$ & $70(52-89)$ \\
\hline LVPedp & Saline & $12(12-15)$ & $13(12-15)^{* *}$ & $15(13-19)^{* *}$ & $16(16-19)^{* *}$ & $16(15-17)$ & $17(16-23)$ \\
\hline $\mathrm{mmHg}$ & Clonidine & $11(9-19)$ & $16(15-29)^{* *}$ & $17(16-26)^{* *}$ & $19(18-26)^{* *}$ & $14(12-22)$ & $22(18-26)$ \\
\hline MPAP & Saline & $22(21-27)$ & $23(22-32)$ & $24(22-31)$ & $25(22-31)$ & $26(22-32)$ & $26(24-34)$ \\
\hline $\mathrm{mmHg}$ & Clonidine & $25(23-27)$ & $26(24-27)$ & $25(24-29)$ & $27(25-32)$ & $30(25-31)$ & $27(25-29)$ \\
\hline LVPdtp$_{\max }$ & Saline & $2210(1705-2555)$ & $2160(1750-2528)$ & $2400(1950-3220)$ & $2830(2510-3630)$ & $3630(2748-3925)$ & $2080(1810-2805)$ \\
\hline $\mathrm{mmHg} \mathrm{s}{ }^{-1}$ & Clonidine & $2510(2105-2935)$ & $1644(1525-2550)$ & $2350(2070-2755)$ & $2450(2179-3260)$ & $2430(2275-3105)$ & $1710(885-2145)$ \\
\hline LVPdtp $_{\min }$ & Saline & $\begin{array}{l}-3070 \\
(-5130-2666)\end{array}$ & $\begin{array}{l}-3120 \\
(-5015-2445)\end{array}$ & $\begin{array}{l}-3290 \\
(-4420-2465)\end{array}$ & $\begin{array}{l}-3200 \\
(-4680-2554)\end{array}$ & $\begin{array}{l}-2850 \\
(-4950-2680)\end{array}$ & $\begin{array}{l}-1820 \\
(-2840-1195)^{* *}\end{array}$ \\
\hline $\mathrm{mmHg}^{-1}$ & Clonidine & $\begin{array}{l}-2510 \\
(-3530-2300)\end{array}$ & $\begin{array}{l}-3800 \\
(-3890-3235)\end{array}$ & $\begin{array}{l}-3340 \\
(-4065-2735)\end{array}$ & $\begin{array}{l}-3080 \\
(-3650-2900)\end{array}$ & $\begin{array}{l}-2900 \\
(-2950-2170)\end{array}$ & $\begin{array}{l}-1100 \\
(-1660-785)^{* *}\end{array}$ \\
\hline LVSWI & Saline & $642(595-820)$ & $688(604-825)$ & $686(595-790)$ & $752(671-896)$ & $686(642-749)$ & $631(393-668)$ \\
\hline $\mathrm{Nm} 10^{-3} \mathrm{~m}^{-2}$ & Clonidine & $435(347-657)$ & $610(516-962)$ & 717 (590-897) & $664(602-819)$ & $609(504-751)$ & 409 (258-616) \\
\hline RVSWI & Saline & $155(148-216)$ & $210(172-231)$ & $203(178-238)$ & $253(190-286)$ & $241(178-272)$ & $284(231-299)$ \\
\hline $\mathrm{Nm} 10^{-3} \mathrm{~m}^{-2}$ & Clonidine & $125(116-200)$ & $148(119-229)$ & $233(169-264)$ & 209 (179-282) & $203(186-292)$ & $271(229-346)$ \\
\hline
\end{tabular}

Parameters of macrohemodynamics. All values are presented as median and quartiles $\left(\mathrm{Q}_{1}-\mathrm{Q}_{3}\right)$ for the investigated time points $\mathrm{BL} 1$ (baseline, premedication), $\mathrm{BL} 2$ (second baseline, after medication), $25 \%$ (exchange of $25 \%$ of exchangeable blood volume (EBV)), $50 \%$ (exchange of $50 \%$ of EBV), $75 \%$ (exchange of $75 \%$ of EBV), $\mathrm{Hb}_{\text {crit }}$ (critical haemoglobin concentration). ${ }^{* *}: p<0.05$ Saline vs. Clonidine

$H R$ heart rate, MAP mean arterial pressure, $C$ cardiac output indexed to BSA, SVRI systemic vascular resistance indexed to BSA, PVRI pulmonary vascular resistance indexed to BSA, CPP coronary perfusion pressure, LVPsys systolic left ventricular pressure, LVPedp enddiastolic left ventricular pressure, MPAP mean pulmonary arterial pressure, $L V P d t p_{\max }$ maximum left ventricular pressure increase, $L V P d t p_{\min }$ maximum left ventricular pressure decrease, $L V S W I$ left ventricular stroke work index, RVSWI right ventricular stroke work index 


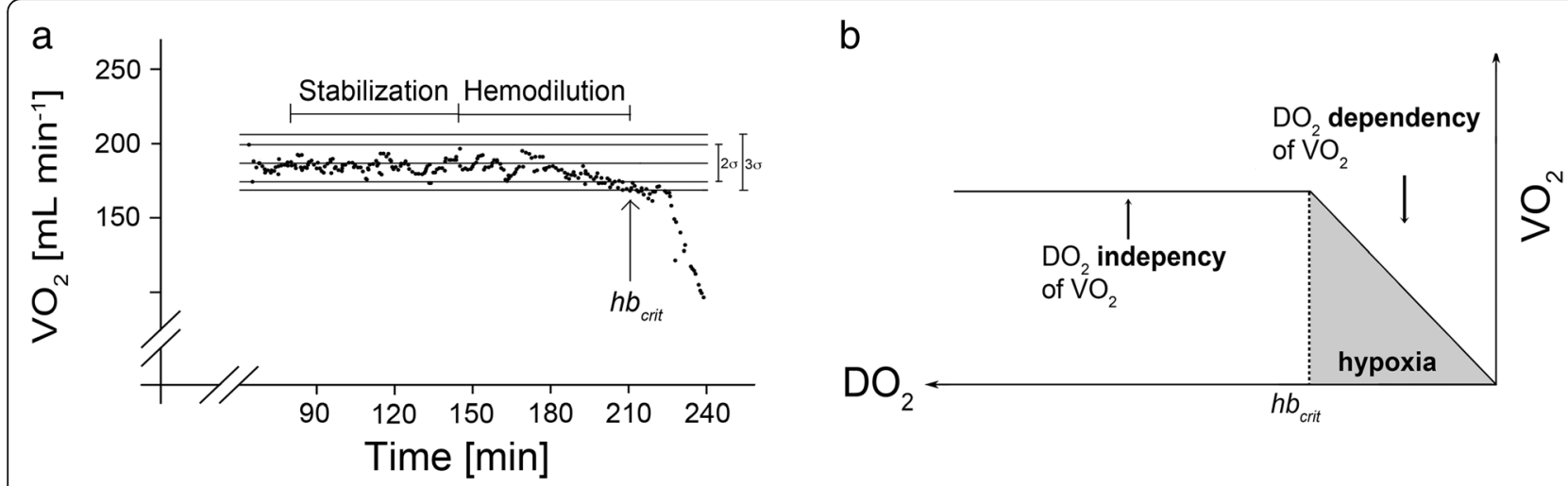

Fig. 1 a Typical example of an oxygen consumption $\left(\mathrm{NO}_{2}\right)$ recording in the course of the experimental protocol. A linear regression analysis including the calculation of standard deviation was performed with $\mathrm{VO}_{2}$ values collected during the 60 -min stabilization period. During the subsequent hemodilution protocol, a critical limitation of $\mathrm{DO}_{2}$ was assumed, when the actually measured $\mathrm{VO}_{2}$ value decreased below the lower $3 \mathrm{~s}$. b Dependency of oxygen consumption $\left(\mathrm{NO}_{2}\right)$ on oxygen delivery $\left(\mathrm{DO}_{2}\right)$ during normovolemic anemia. The graph presentation of Fig. 1 panel is reflected around a vertical axis (with the $x$-axis to the right of the $y$-axis) to match the decreasing $\mathrm{VO}_{2}$ along the timeline of panel a. In panel $\mathrm{b} \mathrm{DO}_{2}$ decreases from left to right along the $x$-axis and $\mathrm{VO}_{2}$ decreases from top to bottom along the $y$-axis. Despite an initial decrease of $\mathrm{DO}_{2}, \mathrm{VO}_{2}$ remains stable over a long period $\left(\mathrm{DO}_{2}\right.$ is independent of $\mathrm{VO}_{2}$ ). If a critical hemoglobin concentration $\left(\mathrm{Hb}_{\text {crit }}\right.$ is reached, $\mathrm{VO}_{2}$ starts to decrease because of a critical restriction $\left(\mathrm{DO}_{2}\right.$ dependent on $\left.\mathrm{VO}_{2}\right)$

60-min stabilization period were included in an online regression analysis. The $\mathrm{VO}_{2}$ values measured during hemodilution were compared to the mean value predicted by the DeltaCrit system; if the measured value was outside a predefined range $\left(3 \times \mathrm{SD}\right.$ of the regression line), the $\mathrm{VO}_{2}$ was considered significantly decreased, and the computer alerted visually and acoustically. This time point was designated as $\mathrm{Hb}_{\text {crit }}$ (Fig. 1b).

\section{Statistical analysis}

Prior to the study, a sample size analysis was conducted using a software package (PS, Power and Sample Size Calculation, Version 3.0, 2009, Vanderbilt University, Tennessee, USA) to estimate the appropriate number of animals. From former studies we anticipated the $\mathrm{Hb}_{\text {crit }}$ around a haemoglobin concentration of $2,7 \mathrm{~g} / \mathrm{dL}( \pm 0.55 \mathrm{~g} / \mathrm{dL})$. We determined a difference of $0.7 \mathrm{~g} / \mathrm{dL}$ as clinical significant. With a two-sided $\alpha$ of 0.05 and a power of $80 \%$, seven animals per group were required for the Student's $t$-test to detect differences in the critical haemoglobin concentration.

Between the saline and clonidine groups $\mathrm{Hb}_{\text {crit }}$ and $\mathrm{EBV}$ were normally distributed, therefore differences between the two study groups were tested using a student's $t$-test for independent samples. Distributions of macrohemodynamic and oxygen transport data were tested by the KolmogorovSmirnov test. Not all data were normally distributed; therefore, data are presented as the median and quartiles (Q1-Q3). A repeated-measurement ANOVA on ranks was performed to detect differences between groups at the main time points: $\mathrm{BL}, \mathrm{AM}$, and $25,50,75 \%$, and $\mathrm{Hb}_{\text {crit. }}$.

Post hoc analysis was performed with a StudentNewman-Keuls (SNK) test to account for multiple comparisons (Statistica 5.1, StatSoft, Tulsa, OK). Statistical significance was designated at $p<0.05$ for all tests.

\section{Results}

No differences were detected at BL between the study groups in age, sex, weight, and all other variables. Values are median $\left(\mathrm{Q}_{1}-\mathrm{Q}_{3}\right)$

\section{Primary end points: $\mathrm{Hb}_{\text {crit }}$ and EBV}

The critical haemoglobin concentration $\left(\mathrm{Hb}_{\text {crit }}\right)$ was reached at $2.2(2.0-2.5) \mathrm{g} \cdot \mathrm{dL}^{-1}$ in the saline group and 2.1 (2.1-2.4) $\mathrm{g} \cdot \mathrm{dL}^{-1}$ in the clonidine group (Fig. 2; n.s.). Hemodilution to $\mathrm{Hb}_{\text {crit }}$ required a hydroxyethyl starch exchange of $88(76-106) \mathrm{mL} \cdot \mathrm{kg}^{-1}$ blood in the saline group and 92 (85-95) $\mathrm{mL} \cdot \mathrm{kg}^{-1}$ in the clonidine group, lasting approximately $83 \mathrm{~min}$ (n.s.). This corresponded to $115 \%$ (86-166 \%) of the blood volume at BL in the saline group and $121 \%(108-124 \%)$ in the clonidine group (Fig. 2; n.s.).

\section{Secondary end points: haemodynamics and myocardial function}

Haemodynamic data are summarized in Table 1 and in Fig. 3. During haemodilution to $\mathrm{Hb}_{\text {crit }}$, cardiac index (CI) was significantly lower at BL2, $25 \%$, and $50 \%$ time points in the clonidine group. Heart rate (HR) was also significantly lower at $\mathrm{BL} 2,25 \%$, and $\mathrm{Hb}_{\text {crit }}$ in the clonidine group. Mean arterial pressure (MAP) and coronary perfusion pressure (CPP) showed no intergroup differences, despite the significantly higher values in the clonidine group at BL2. Systemic vascular resistance (SVRI), left ventricular systolic $\left(\mathrm{LVP}_{\text {sys }}\right)$, and left ventricular end diastolic pressure $\left(\mathrm{LVP}_{\text {edp }}\right)$ were significantly higher in the clonidine group at BL2 and at $25 \%$, due to clonidine's initial $\alpha_{1}$-mediated vasoconstriction. The significantly higher SVRI, $\mathrm{LVP}_{\text {sys }}$, and $\mathrm{LVP}_{\text {edp }}$ were not maintained during the progression to $\mathrm{Hb}_{\text {crit }}$. 


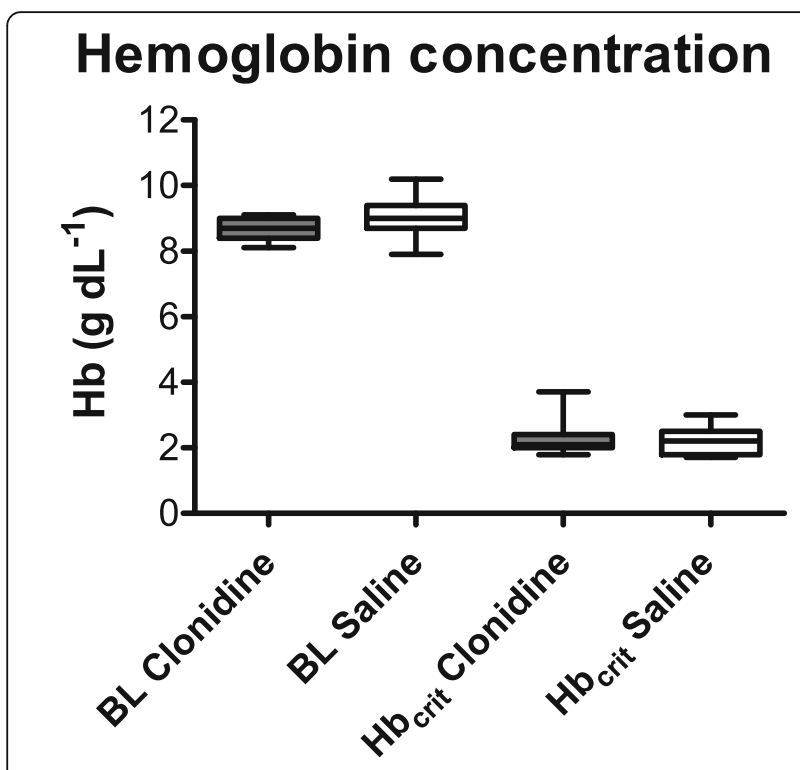

\section{Exchangeable Blood Volume}

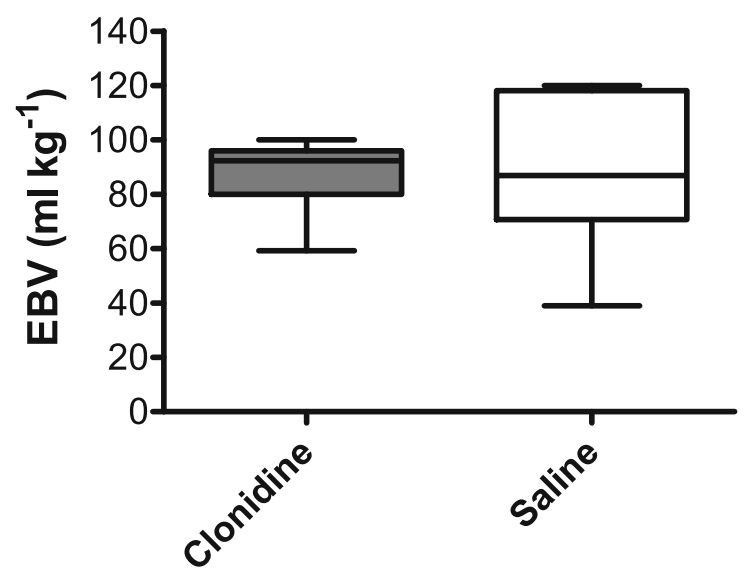

Fig. 2 Haemoglobin concentration at $\mathrm{BL}$ and $\mathrm{Hb}_{\text {crit. }}$ Grouped boxplots of the arterial haemoglobin concentration $\left(\mathrm{g} \cdot \mathrm{dL}^{-1}\right)$ at $\mathrm{BL}$ and $\mathrm{Hb}_{\text {crit. }}$. The results are presented pairwise as boxplots (median line) with whiskers (min to max). Data from the clonidine group are coloured white, and saline group data are dark grey. No difference was demonstrated between the groups. BL (baseline, premedication); $\mathrm{Hb}_{\text {crit }}$ (critical haemoglobin concentration). Exchangeable blood volume (EBV). Boxplots of the exchangeable blood volume $\left(\mathrm{mL} \cdot \mathrm{kg}^{-1}\right)$ until $\mathrm{Hb}_{\text {crit }}$ was reached. The results are presented pairwise as the median and quartiles $\left(Q_{1}-Q_{3}\right)$. No differences were demonstrated between the groups. $\mathrm{Hb}_{\text {crit }}$ (critical haemoglobin concentration)

Pulmonary vascular resistance (PVRI) and mean pulmonary pressure (MPAP) similarly trended in both groups and showed no statistically significant change. The left ventricular stroke work index (LVSWI) and right ventricular stroke work index (RVSWI) were similar between the two groups during the procedure. Left ventricular contractility
$\left(\mathrm{LVP}_{\mathrm{dtpmax}}\right)$ showed no intergroup difference, but the left ventricular relaxation $\left(\mathrm{LVP}_{\mathrm{dtpmin}}\right)$ was significantly lower in the clonidine group at $\mathrm{Hb}_{\text {crit }}$.

\section{Secondary end points: oxygen transport and tissue oxygenation}

Oxygen transport and tissue oxygenation variables are presented in Table 2 and in Fig. 4. Changes in oxygen transport parameters and tissue oxygenation at BL2 and during hemodilution to $\mathrm{Hb}_{\text {crit }}$ were similar between the groups.

Oxygen delivery $\left(\mathrm{DO}_{2}\right)$ and oxygen consumption $\left(\mathrm{VO}_{2}\right.$ $\mathrm{mi})$ were significantly lower in the clonidine group at BL2, $25 \%$, and $50 \%$. Arterial serum lactate and arterial $\mathrm{pH}$ did not differ significantly between the groups and remained stable throughout the procedure.

At BL2, arterio-venous difference in $\left(\mathrm{avDO}_{2}\right)$ and oxygen extraction ratio $\left(\mathrm{O}_{2}-\mathrm{ER}\right)$ were significantly higher, whereas mixed-venous oxygen saturation $\left(\mathrm{SvO}_{2}\right)$ was significantly lower in the clonidine group. During hemodilution from baseline to the study endpoint $\left(\mathrm{Hb}_{\text {crit }}\right)$, no ventricular arrhythmia, ectopia, ST-level changes, or other electrocardiographic arrhythmias were encountered in either group.

\section{Discussion}

The present study indicates foremost that a high dose of intravenous clonidine did not critically restrict acute anaemia compensatory mechanisms in a swine model. This is reflected in identical critical haemoglobin concentrations and exchangeable blood volumes observed in both study groups.

Alpha-2 agonists mediate their cardioprotective effects by attenuated catecholamine release and thus partially inhibited stress-induced tachycardia. Apart from these haemodynamic effects, $\alpha_{2}$-agonists also induce analgesia, anxiolysis, and sedation through central presynaptic $\alpha_{2}$-adrenergic receptors [16]. Furthermore, whole body and myocardial oxygen consumption decrease under $\alpha_{2}$-agonist treatment [6].

Increased heart rate is one of the compensatory mechanisms for acute dilutional anaemia, and myocardial oxygen consumption is an important determinant of the outer limits of this compensatory mechanism; yet, the influence of $\alpha_{2}$-agonists on this effect and by that on anaemia tolerance is unclear. Potentially, clonidine induced reduction in heart rate may impair compensatory potential, but conversely, the decreased oxygen consumption may improve anaemia tolerance. To date, no existing study comprehensively investigates the effects of perioperative $\alpha_{2}$ agonists on anaemia tolerance.

Unfortunately, "anaemia tolerance" is poorly defined, and consequently, its limits are difficult to measure. For example, short periods of anaemia and concomitant tissue hypoxia can be sustained without any sequelae [4], although the individual anaemia tolerance of several 


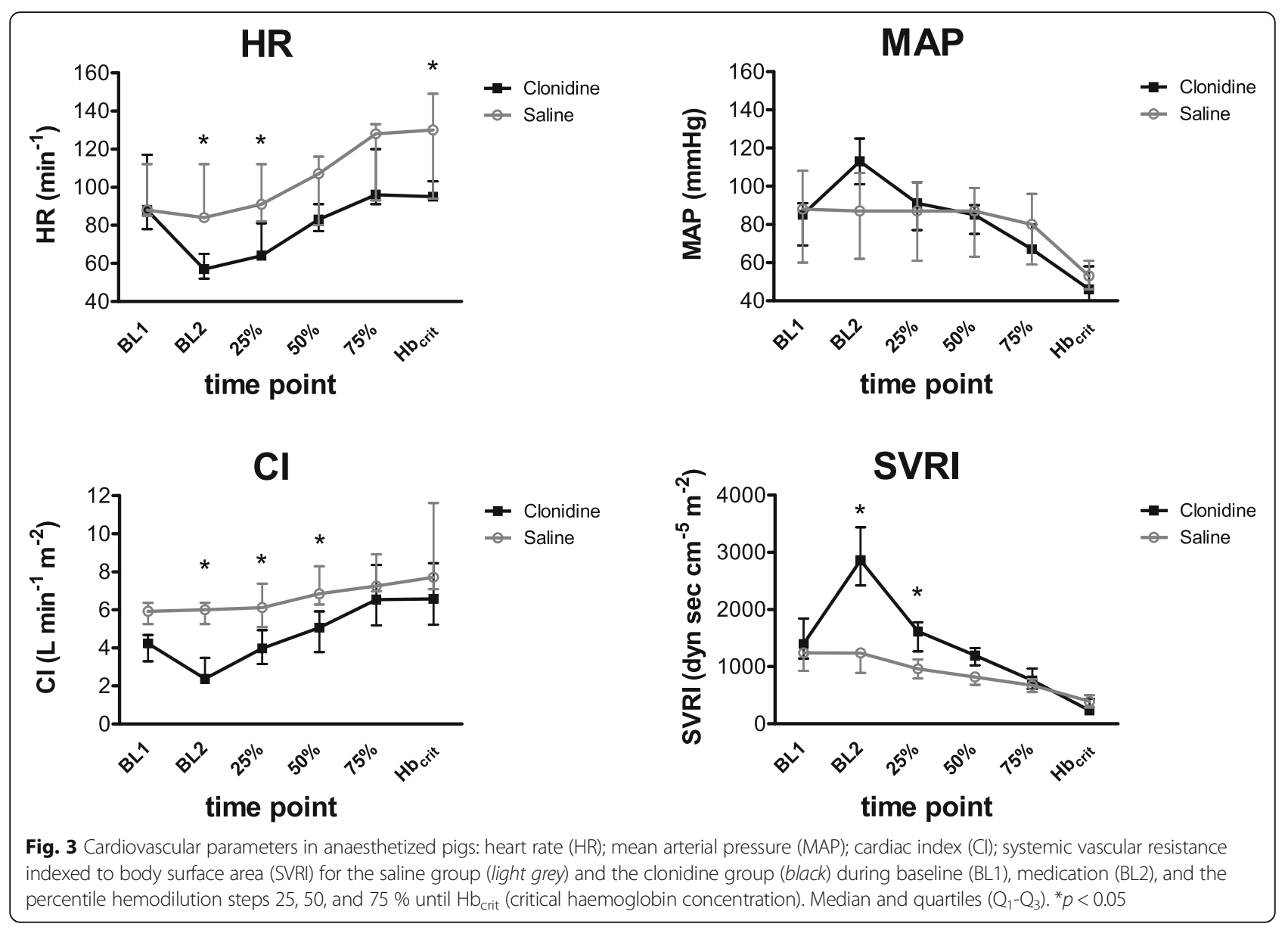

organs may be exceeded. Furthermore, organ specific markers of tissue hypoxia (e. g. ECG changes, cerebral function, urinary output) likely indicate that the outer limit of anaemia has been surpassed at an earlier time point, but do not reflect "anaemia tolerance" comprehensively because the complete organism is not considered [17-19].

Several studies demonstrate that a significant decline in whole body oxygen consumption is accompanied by inadequate tissue oxygenation, and as a consequence this parameter has been used regularly as measure for anaemia tolerance $[20,21]$. The corresponding haemoglobin concentration is called "critical haemoglobin concentration $\left(H b_{\text {crit }}\right)$." Several experimental studies have observed haemodynamic decompensation [22], increased lactate, and elevate catecholamine concentrations once $\mathrm{Hb}_{\text {crit }}$ was reached that resulted in the deaths of all animals within $3 \mathrm{~h}$ [14]. In a recent study, we showed that $\mathrm{Hb}_{\text {crit }}$ is accompanied by widespread tissue hypoxia in several organs, determined by quantification of hypoxia-specific changes in protein and RNA concentrations [20].

While this approach does not guarantee that the tissues are undamaged by hypoxia before $\mathrm{Hb}_{\text {crit }}$ is reached, it is apparent that upon reaching the $\mathrm{Hb}_{\text {crit }}$, the individual animals are similarly restricted in tissue oxygenation, therefore, $\mathrm{Hb}_{\text {crit }}$ is a reasonable measure of global anaemia tolerance [20].

Although no pig specific data on clonidine dosage exist, the dosage used in our model was chosen deliberately high compared to the rather few existing studies. While Iber et al. established sympathicolysis with $1 / 10$ of our dose in a swine model [23], we failed to identify hemodynamic changes in several dose finding experiments with this approach. Finally, we titrated the medication up to a bolus of $20 \mu \mathrm{g} \cdot \mathrm{kg}^{-1}$ and a continuous rate of $15 \mu \mathrm{g} \cdot \mathrm{kg}^{-1} \cdot \mathrm{h}^{-1}$ to ensure a hemodynamic relevant sympatholytic effect of the drug tested. This is bolstered by the distinct increase in mean arterial pressure and a concomitant cardiac output decline following the initial clonidine bolus. The initial peripheral vasoconstriction is mediated by the partial affinity of clonidine to postsynaptic $\alpha_{1}$-receptors, until the higher affinity to central presynaptic $\alpha_{2}$-receptors prevails [24]. However, clonidine concentration was not measured, and as a consequence we cannot guarantee that clonidine concentration was consistent throughout the protocol.

The observed haemodynamic effects essentially depend on the chosen therapeutic scheme; in daily clinical practice, clonidine dosage is much lower, and the subsequent 
Table 2 Oxygen transport and tissue oxygenation

\begin{tabular}{|c|c|c|c|c|c|c|c|}
\hline & Group & BL1 & BL2 & $25 \%$ & $50 \%$ & $75 \%$ & $\mathrm{Hb}_{\text {crit }}$ \\
\hline $\mathrm{Hb}$ & Saline & $9,0(8,9-9,3)$ & $8,6(8,5-9,2)$ & $6,0(5,6-6,4)^{* *}$ & $4,3(3,9-4,5)$ & $3,0(2,7-3,1)$ & $2,2(2-2,5)$ \\
\hline $\mathrm{g} \mathrm{dl}^{-1}$ & Clonidine & $8,7(8,5-9)$ & $8,7(8,4-8,9)$ & $6,5(6,1-6,7)^{* *}$ & $4,2(4,1-4,7)$ & $3,1 \quad(2,9-3,4)$ & $2,1(2,1-2,4)$ \\
\hline $\mathrm{paO}_{2}$ & Saline & $90(89-102)$ & $89(88-91)$ & 93 (84-95) & 93 (92-97) & 94 (88-98) & $108(93-113)$ \\
\hline $\mathrm{mmHg}$ & Clonidine & $92(85-101)$ & 94 (90-109) & $85(81-101)$ & $93(80-104)$ & $93(81-102)$ & $109(94-122)$ \\
\hline $\mathrm{pvO}_{2}$ & Saline & $36(36-38)$ & $37(36-44)^{* *}$ & $41(36-44)$ & $35(32-37)$ & $36(33-42)$ & $26(22-28)$ \\
\hline $\mathrm{mmHg}$ & Clonidine & $43(41-45)$ & $27(26-32)^{* *}$ & $32(31-36)$ & $36(33-40)$ & $29(28-31)$ & $26(24-32)$ \\
\hline $\mathrm{CaO}_{2}$ & Saline & $12,2(12-12,5)$ & $11,6(11,5-12,3)$ & $8,3(7,7-8,6)^{* *}$ & $6,1(5,4-6,2)$ & $4,2(3,8-4,5)$ & $3,3(3-3,6)$ \\
\hline $\mathrm{ml} \mathrm{dl^{-1 }}$ & Clonidine & $11,8(11,5-12,2)$ & $11,8(11,5-11,9)$ & $8,9(8,3-9,1)^{* *}$ & $5,9(5,7-6,4)$ & $4,4(4,1-4,8)$ & $3,2(3,1-3,4)$ \\
\hline $\mathrm{avDO}_{2}$ & Saline & $3,9(3,2-4,8)$ & $3,4(3,1-4,6)^{* *}$ & $2,4(1,8-3,2)$ & $2,3(1,9-2,8)$ & $2,0(1,9-2,2)$ & $1,9(1,7-2,1)$ \\
\hline $\mathrm{ml} \mathrm{dl}^{-1}$ & Clonidine & $4,7(4,2-5,0)$ & $6,3(5,6-7,5)^{* *}$ & $3,4(2,5-4,0)$ & $2,8(2,3-2,8)$ & $2,1(1,4-2,1)$ & $1,4(1,1-1,9)$ \\
\hline $\mathrm{O}_{2}-\mathrm{ER}$ & Saline & $31,3(25,3-39,3)$ & $29,7(26,2-38,3)^{* *}$ & $31,8(23,6-41,5)$ & $40,3(37-46,4)$ & $49,3(48,1-49,9)$ & $56,7(54,1-58,2)$ \\
\hline$\%$ & Clonidine & $41,2(34,8-43,7)$ & $58,5(47,5-63,4)^{* *}$ & $41,3(31,3-44,2)$ & $47,5(37,4-48,2)$ & $49,0(28,5-50,7)$ & $44,7(34,2-49,1)$ \\
\hline $\mathrm{SaO}_{2}$ & Saline & $98,7(97,9-99,1)$ & $98,5(98,4-98,7)$ & $98,7(97,9-99,0)$ & $99,0(98,7-99,3)$ & $99,1(98,7-99,2)$ & $99,3(99,0-99,5)$ \\
\hline$\%$ & Clonidine & $98,6(98,1-99,0)$ & $98,6(98,0-99,1)$ & $98,3(98,3-98,7)$ & $98,6(98,0-98,9)$ & $98,9(98,2-99,0)$ & $99,1(98,9-99,1)$ \\
\hline $\mathrm{SvO}_{2}$ & Saline & $68,4(59,4-75,5)$ & $70,0(61,8-73,5)^{* *}$ & $69,1(59-76,6)$ & $61,9(55,4-64,4)$ & $52,2(51,5-53,4)$ & $45,5(44,3-48,3)$ \\
\hline$\%$ & Clonidine & $57,8(56,1-65,0)$ & $41,7(35,8-51,3)^{* *}$ & $60,2(55,7-68,9)$ & $53,2(53,2-63,5)$ & $52,8(50,3-71,0)$ & $57,1(55,5-70,0)$ \\
\hline $\mathrm{DO}_{2 \mathrm{i}}$ & Saline & $607(569-623)$ & $636(612-677)^{* *}$ & $512(455-542)^{* *}$ & $430(393-469)^{* *}$ & $300(284-348)$ & $313(266-336)$ \\
\hline $\mathrm{ml} \mathrm{min} \mathrm{m}^{-1} \mathrm{~m}^{-2}$ & Clonidine & $512(503-565)$ & $269(261-387)^{* *}$ & $342(288-418)^{* *}$ & $281(258-382)^{* *}$ & $283(228-394)$ & $236(190-341)$ \\
\hline $\mathrm{VO}_{2 \mathrm{im}}$ & Saline & 187 (180-196) & $190(183-197)^{* *}$ & $185(183-197)^{* *}$ & 179 (170-196) & 179 (175-193) & $162(153-181)^{* *}$ \\
\hline $\mathrm{ml} \min ^{-1} \mathrm{~m}^{-2}$ & Clonidine & 175 (161-193) & $145(140-159)^{* *}$ & $181(168-187)^{* *}$ & 183 (174-199) & $175(161-179)$ & $130(122-157)^{* *}$ \\
\hline $\mathrm{VO}_{2 \mathrm{ic}}$ & Saline & $209(188-247)$ & $231(131-259)$ & $152(118-211)$ & $162(144-198)$ & $161(147-178)$ & $169(157-201)^{* *}$ \\
\hline $\mathrm{ml} \min ^{-1} \mathrm{~m}^{-2}$ & Clonidine & $205(142-223)$ & $171(129-236)$ & $146(102-157)$ & $132(88-146)$ & $123(94-166)$ & $91(53-158)^{* *}$ \\
\hline Lactate & Saline & $1,3(1,2-1,5)$ & $1,3(1,1-1,6)$ & $1,2(1-1,4)$ & $1,1(0,9-1,2)$ & $1,1(1-1,1)$ & $1,6(1,3-1,9)$ \\
\hline $\mathrm{mmol} \mathrm{I}{ }^{-1}$ & Clonidine & $1,3(1-1,5)$ & $1,6(1,2-1,6)$ & $1,2(0,9-1,4)$ & $1,0(0,8-1,2)$ & $0,9(0,8-1,2)$ & $1,9(1,4-2,1)$ \\
\hline
\end{tabular}

Parameters of oxygen transport and tissue oxygenation. All values are presented as median and quartiles $\left(\mathrm{Q}_{1}-\mathrm{Q}_{3}\right)$ for the investigated time points $\mathrm{BL} 1$ (baseline, premedication), BL2 (second baseline, after medication), $25 \%$ (exchange of $25 \%$ of EBV), $50 \%$ (exchange of $50 \%$ of EBV), $75 \%$ (exchange of $75 \%$ of EBV), Hb $\mathrm{brit}$ (critical hemoglobin concentration). ${ }^{* *}: p<0.05$ Saline vs. Clonidine

$\mathrm{Hb}$ hemoglobin concentration, $\mathrm{PaO}_{2}$ arterial oxygen partial pressure, $\mathrm{PvO}_{2}$ central venous oxygen partial pressure, $\mathrm{CaO}$ arterial oxygen content, avDO $\mathrm{O}_{2}$ arteriovenous difference in oxygen content, $\mathrm{O}_{2} \mathrm{nER}$ oxygen extraction, $\mathrm{SaO}_{2}$ arterial hemoglobin saturation, $\mathrm{SvO}_{2}$ mixed venous hemoglobin saturation, $\mathrm{DO} \mathrm{O}_{2 i}$ oxygen delivery indexed to $\mathrm{BSA}, \mathrm{VO}_{2 i m}$ measured oxygen consumption indexed to $\mathrm{BSA}, \mathrm{VO}_{2 i c}$ calculated oxygen consumption, Lactate arterial serum lactate concentration, $p H$ negative logarithm of the molar concentration of dissolved hydronium ions in a solution

haemodynamic changes differ essentially from our observation. After an initial, modest increase, the mean arterial blood pressure and heart rate usually decline (Table 1, Fig. 3). Although our model does not mimic this clinical approach, we can deduce from our data that clonidine only slightly influences anaemia tolerance. $\mathrm{Hb}_{\text {crit }}$ has been observed at concentrations as low as $2.1 \mathrm{~g} \cdot \mathrm{dL}^{-1}$ during our relative clonidine overdosage; the haemodynamic changes in clonidine treated animals were comparable to those in untreated animals during hemodilution, therefore normal clonidine dosage will presumably only negligibly influence haemodynamic changes during acute anaemia.

One possible explanation for the mild hemodynamic effects observed during hemodilution might originate from the specific compensation mechanisms during acute anemia. In anesthetized subjects, the reduction of oxygen content of the blood is compensated by an increase in cardiac output via an increase in stroke volume
$[25,26]$. This increase in stroke volume and thus cardiac output is mainly effected by the Frank-Starling mechanism: the decrease of blood viscosity due to hemodilution reduces the peripheral resistance by shear stress induced NO-liberation from the vessel-endothelium and thus increases venous return [27, 28]. Therefore, in contrast to the pathophysiology of hypovolemic/haemorrhagic shock, in acute, normovolemic anemia oxygen delivery to the tissues is not maintained by increased sympathetic tone, but by the Frank-Starling mechanism [29]. This might explain the lack of hemodynamic changes by a drug that basically mediates its cardioprotective effects by attenuation of catecholamine release.

Bolus clonidine administration reduced $\mathrm{VO}_{2}$ in our model and may therefore have optimized the oxygen consumption/delivery balance. Several authors have similarly observed decreased $\mathrm{VO}_{2}$ and energy expenditure after clonidine administration. $[6,10,30]$ However, 


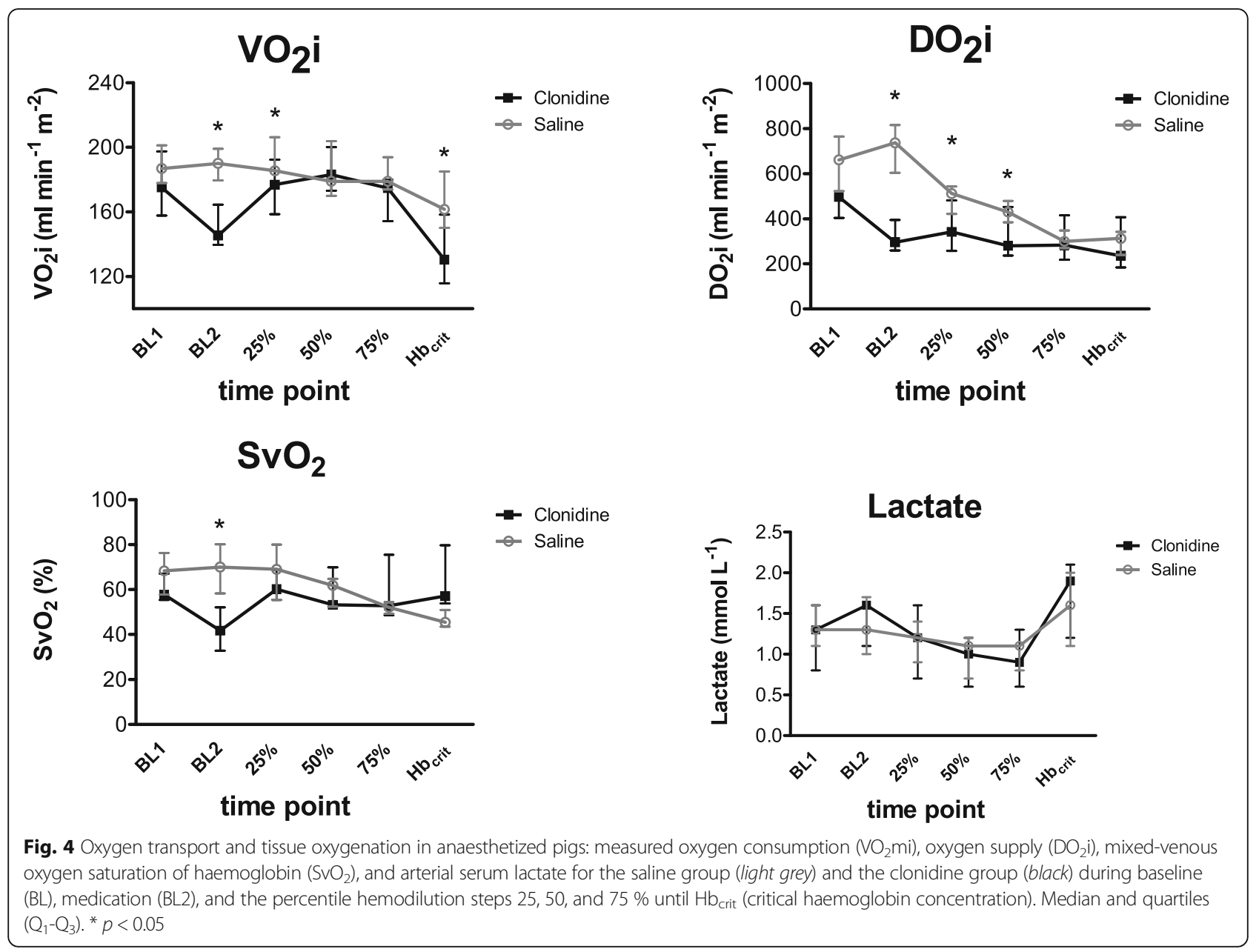

this effect was limited in our model, occurring only at the initial time points following administration (BL2, $25 \%)$ where it could be attributed to severe bradycardia. Presumably, haemodynamic changes during hemodilution were too small to influence $\mathrm{VO}_{2}$ significantly.

Underdosage of clonidine seems rather unlikely given the observed haemodynamic changes, therefore the mechanisms underlying these findings remain unknown. It is particularly unclear whether a more distinctive effect on $\mathrm{VO}_{2}$ may have caused even more pronounced anaemia tolerance.

Despite significant haemodynamic differences between the two experimental groups, only negligible differences were observed in oxygen transport and tissue oxygenation. Even at very low $\mathrm{Hb}$ levels, there were no differences observed in oxygen consumption, oxygen delivery, arterial serum lactate concentration, and acid base balance between both study groups. It can therefore be surmised that the high clonidine dose did not critically restrict tissue oxygenation during acute anaemia.

Several study limitations warrant discussion. We investigated the effects of clonidine on anaemia tolerance in young, healthy pigs. Pigs are a generally accepted animal model for hemodynamic shock and multiple studies have shown that the limits of oxygen supply are comparable for anesthetized, paralyzed healthy pigs and anesthetized, paralyzed, otherwise healthy humans [4, 14, 31-34]. However, in clinical practice, patients with concomitant cardiac risks or comorbidities are the primary population administered perioperative $\alpha_{2}$-adrenergic agonists $[7,8]$. Consequently, our model may differ from clinical practice because compensatory mechanisms for acute anaemia may be different between healthy patients and those with significant cardiac disease. However, our results help to elucidate underlying mechanisms of anemia tolerance during clonidine medication.

We demonstrated that $\mathrm{Hb}_{\text {crit }}$ did not differ between control and clonidine treated animals, but this does not indicate that moderate anaemia $\left(\mathrm{Hb} 8-10 \mathrm{~g} \cdot \mathrm{dL}^{-1}\right)$ can be sustained similarly in both groups in clinical practice. Using our model we cannot rule out that in some organs oxygen transport and tissue oxygenation are restricted more severely by clonidine than others, and as a result, anaemia tolerance may differ between different organs. 
Dexmedetomidine was described to have even stronger $\alpha_{2}$-selective effects than clonidine [35]. A comparison of both drugs during acute anemia might reveal further insight into the effects of $\alpha_{2}$-agonists during acute anemia. $\beta$-adrenergic receptor antagonists are a common medication in elderly patients and have comparable hemodynamic effects to $\alpha_{2}$-agonists. Perioperative $\beta$-blockade might influence cardiac compensatory mechanisms for acute blood losses and thus reduce the patients natural anemia tolerance [36].

Finally, since this study was planned using sample size calculations based on the $\mathrm{Hb}_{\text {crit }}$ as the main outcome parameter, it might be underpowered to detect all differences in the secondary outcome parameters (hemodynamics, oxygen transport)- at each timepoint with multiple comparisons.

In summary, we demonstrated that the limitations of extreme anaemia are independent of clonidine therapy, and despite the study limitations, this indicates a similar anaemia tolerance in both experimental groups. Clinically, these results suggest that clonidine administration alone does not justify blood transfusion at higher haemoglobin concentrations. However, despite these results, transfusion at higher thresholds may still be necessary due to concomitant diseases that triggered clonidine therapy.

\section{Conclusion}

In conclusion, extended central sympathicolysis with clonidine has no influence on the critical haemoglobin concentration and global anaemia tolerance in young, healthy pigs. Based on these findings, blood transfusion cannot be justified at considerably higher haemoglobin concentrations after administering clonidine alone. This approach supports identical transfusion schemata for patients with or without perioperative central sympathicolysis, however safety studies in humans, particularly cardiac compromised patients, are needed to verify our results clinically.

\section{Appendix}

Body surface area (BSA in $\mathrm{m}^{2}$ ) was calculated according to Holt et al. [37]

$$
B S A=k \times B W^{\frac{2}{3}}
$$

where $\mathrm{BW}=$ body weight (in $\mathrm{kg}$ ) and $\mathrm{k}=9$.

Cardiac index was calculated as:

$$
C I=C O / B S A
$$

where $\mathrm{CO}$ is cardiac output.

Peripheral vascular resistance index was calculated as:

$$
S V R I=(M A P-C V P) \times \alpha / C I
$$

where SVRI is systemic vascular resistance, $\alpha$ is a constant factor necessary to adjust the formula to the different dimensions, CVP is central venous pressure.
Arterial $\mathrm{O}_{2}$ content $\left(\mathrm{CaO}_{2}\right)$ was calculated as:

$$
\mathrm{CaO}_{2}=\left(\mathrm{Hb} \times \mathrm{SaO}_{2} \times 1.34\right)+p a \mathrm{O}_{2} \times 0.003
$$

Total body $\mathrm{O}_{2}$ delivery $\left(\mathrm{DO}_{2} \mathrm{I}\right)$ was calculated as follows:

$$
\mathrm{DO}_{2} \mathrm{I}=\mathrm{CI} \times \mathrm{CaO}_{2}
$$

\section{Acknowledgements}

Not applicable.

\section{Funding}

This work was supported by the Clinic of Anaesthesiology, Intensive Care, and Pain Therapy, Goethe-University Hospital, Frankfurt, Germany.

\section{Availability of data and materials}

The datasets during and/or analysed during the current study available from the corresponding author on reasonable request.

\section{Authors' contributions}

PL contributed to conception and design of the study, acquisition, analysis, and interpretation of presented data, drafting the article, and final approval of the version to be published. HK contributed to acquisition, and interpretation of presented data, helped draft the manuscript. BH \&MK contributed to acquisition, and interpretation of presented data. KZ participated in critical revision of the article for important intellectual content. PR participated in critical revision of the article for important intellectual content. JM contributed to conception and design of the study, statistical analysis and interpretation of presented data, critical revision of the article for important intellectual content and final approval of the version to be published. All authors read and approved the final manuscript.

\section{Competing interests}

The authors declare that they have no competing interests.

\section{Consent for publication}

All authors have read the final manuscript and consent to publication in BMC Anesthesiology.

\section{Ethics approval and consent to participate}

The experimental protocol was approved by the Animal Care Committee (Regierungspräsidium Darmstadt, Hessen, F 143/18). The experiments were performed in 14 pigs (Deutsche Landrasse) of either sex (mean body weight $24.1 \pm 2.4 \mathrm{~kg}$ ). The animals were treated in accordance with the Principles of Laboratory Animal Care (National Institute of Health publications 86-23, 1985).

\section{Author details}

${ }^{1}$ Clinic of Anesthesiology and Intensive Care Medicine, Sana Klinikum Offenbach, Offenbach, Germany. ${ }^{2}$ Division of Anaesthesiology, Balgrist University Hospital Zurich, Zurich, Switzerland. ${ }^{3}$ Division of Kardiology, Department of Internal Medicine, University Hospital Frankfurt, Frankfurt am Main, Germany. ${ }^{4}$ Department of Anesthesiology, Intensive Care Medicine and Pain Therapy, University Hospital Frankfurt, Frankfurt am Main, Germany. ${ }^{5}$ Department of Anaesthesiology and Intensive Care Medicine, University Hospital Tübingen, Tübingen, Germany. ${ }^{6}$ Department of Anesthesia and Intensive Care, Faculty of Medicine of the Kepler University Linz, 4021 Linz, Austria.

Received: 10 December 2015 Accepted: 29 September 2016 Published online: 12 October 2016

\section{References}

1. Kozek-Langenecker S a, Afshari A, Albaladejo P, Santullano CAA, De Robertis E, Filipescu DC, et al. Management of severe perioperative bleeding: guidelines from the European Society of Anaesthesiology. Eur J Anaesthesiol. 2013;30:270-382.

2. Ickx BE, Rigolet M, Van der Linden PJ. Cardiovascular and metabolic response to acute normovolemic anemia. Anesthesiology. 2000;93:1011-6.

3. Kronecker $\mathrm{H}$. Kritisches und experimentelles über lebensrettende infusionen von kochsalzlösungen bei hunden. Corresp für Schweizer Ärzte. 1886;16:447-55. 
4. Dai J, Tu W, Yang Z, Lin R. Case report: intraoperative management of extreme hemodilution in a patient with a severed axillary artery. Anesth Analg. 2010;111:1204-6.

5. Fleisher L, Beckman J, Brown K, Calkins H, Chaikof EL, Fleischmann KE, et al. ACCF/AHA focused update on perioperative beta blockade incorporated into the ACC/AHA 2007 guidelines on perioperative cardiovascular evaluation and care for noncardiac surgery. J Am Coll Cardiol. 2009;2009(54):e13-118.

6. Taittonen MT, Kirvelä OA, Aantaa R, Kanto JH. Effect of clonidine and dexmedetomidine premedication on perioperative oxygen consumption and haemodynamic state. Br J Anaesth. 1997;78:400-6.

7. Wijeysundera DN, Bender JS, Beattie WS. Alpha-2 adrenergic agonists for the prevention of cardiac complications among patients undergoing surgery. Cochrane database Syst Rev. 2009;7(4):CD004126. doi: 10.1002/ 14651858.CD004126.pub2.

8. Wallace AW, Galindez D, Salahieh A, Layug EL, Lazo E, Haratonik K, et al. Effect of clonidine on cardiovascular morbidity and mortality after noncardiac surgery. Anesthesiology. 2004;101:284-93.

9. Kitakaze M, Hori M, Gotoh K, Sato H, Iwakura K, Kitabatake A, et al. Beneficial effects of alpha 2-adrenoceptor activity on ischemic myocardium during coronary hypoperfusion in dogs. Circ Res. 1989;65:1632-45.

10. Takahashi H, Nishikawa T, Mizutani T, Handa F. Oral clonidine premedication decreases energy expenditure in human volunteers. Can J Anaesth. 1997:44:268-72.

11. Pichot C, Ghignone M, Quintin L. Dexmedetomidine and clonidine: from second- to first-line sedative agents in the critical care setting? J Intensive Care Med. 2012;27:219-37.

12. Bradley EC, Barr JW. Determination of blood volume using indocyanine green (cardio-green) dye. Life Sci. 1968;7:1001-7.

13. Cain SM. Oxygen delivery and uptake in dogs during anemic and hypoxic hypoxia. J Appl Physiol. 1977;42:228-34.

14. Meier J, Kemming Gl, Kisch-Wedel H, Wölkhammer S, Habler OP. Hyperoxic ventilation reduces 6-hour mortality at the critical hemoglobin concentration. Anesthesiology. 2004;100:70-6.

15. Meier J, Wölkhammer S, Habler O. The DeltaCrit System (DCS): a computer program for standardized bedside detection of critical oxygen delivery using the Deltatrac II metabolic monitor. Comput Biol Med. 2003;33:395-405.

16. Kamibayashi T, Maze M. Clinical uses of alpha2 -adrenergic agonists. Anesthesiology. 2000;93:1345-9.

17. Weiskopf RB, Feiner J, Hopf H, Viele MK, Watson JJ, Lieberman J, et al. Heart rate increases linearly in response to acute isovolemic anemia. Transfusion. 2003:43:235-40

18. Lauscher P, Kertscho H, Raab L, Habler O, Meier J. Changes in heart rate variability across different degrees of acute dilutional anemia. Minerva Anestesiol. 2011;77:943-51.

19. Weiskopf RB, Kramer JH, Viele M, Neumann M, Feiner JR, Watson JJ, et al. Acute severe isovolemic anemia impairs cognitive function and memory in humans. Anesthesiology. 2000;92:1646-52.

20. Lauscher $P$, Kertscho $H$, Schmidt $O$, Zimmermann R, Rosenberger $P$, Zacharowski K, et al. Determination of organ-specific anemia tolerance. Crit Care Med. 2013;41:1037-45.

21. Van der Linden P, Rausin I, Deltell A, Bekrar Y, Gilbart E, Bakker J, et al. Detection of tissue hypoxia by arteriovenous gradient for $\mathrm{PCO} 2$ and $\mathrm{pH}$ in anesthetized dogs during progressive hemorrhage. Anesth Analg. 1995:80:269-75.

22. Habler OP, Kleen MS, Podtschaske H, Hutter JW, Tiede M, Kemming Gl, et al. The effect of acute normovolemic hemodilution (ANH) on myocardial contractility in anesthetized dogs. Anesth Analg. 1996;83:451-8.

23. Iber T, Roesner JP, Mutz C, Werner B, Peters E, Brüderlein K, et al. [Influence of clonidine-induced systemic sympathicolysis on oxygenation and perfusion of the liver. Investigations with healthy pigs under general anesthesia. Anaesthesist. 2007:56:470-7.

24. Doxey JC, Frank LW, Hersom AS. Studies on the pre- and postjunctional activities of alpha-adrenoreceptor agonists and their cardiovascular effects in the anaesthetized rat. J Auton Pharmacol. 1981;1:157-69.

25. Messmer K, Klövekorn W, Holper K, Sunder-Plassmann L. Circulatory significance of hemodilution: rheological changes and limitations. Adv Microcirc. 1972;4:1-77.

26. Habler OP, Messmer KF. The physiology of oxygen transport. Transfus Sci. 1997; 18:425-35.
27. Messmer K, Sunder-Plassmann L, Jesch F, Görnandt L, Sinagowitz E, Kessler M. Oxygen supply to the tissues during limited normovolemic hemodilution. Res Exp Med (Berl). 1973;159:152-66.

28. Tsai AG, Friesenecker B, McCarthy M, Sakai H, Intaglietta M. Plasma viscosity regulates capillary perfusion during extreme hemodilution in hamster skinfold model. Am J Physiol. 1998;275(6 Pt 2):H2170-80.

29. Murray JF, Escobar E. Circulatory effects of blood viscosity: comparison of methemoglobinemia and anemia. J Appl Physiol. 1968;25:594-9.

30. Liatsi D, Tsapas B, Pampori S, Tsagourias M, Pneumatikos I, Matamis D. Respiratory, metabolic and hemodynamic effects of clonidine in ventilated patients presenting with withdrawal syndrome. Intensive Care Med. 2009;35:275-81.

31. Fontana JL, Welborn L, Mongan PD, Sturm P, Martin G, Bünger R. Oxygen consumption and cardiovascular function in children during profound intraoperative normovolemic hemodilution. Anesth Analg. 1995;80:219-25.

32. Zollinger $A$, Hager $P$, Singer $T$, Friedl HP, Pasch $T$, Spahn DR. Extreme hemodilution due to massive blood loss in tumor surgery. Anesthesiology. 1997:87:985-7.

33. Meier J, Pape A, Loniewska D, Lauscher P, Kertscho H, Zwissler B, et al. Norepinephrine increases tolerance to acute anemia. Crit Care Med. 2007;35:1484-92.

34. Perez-de-Sá V, Roscher R, Cunha-Goncalves D, Larsson A, Werner O. Mild hypothermia has minimal effects on the tolerance to severe progressive normovolemic anemia in Swine. Anesthesiology. 2002;97:1189-97.

35. Masuki S, Dinenno FA, Joyner MJ, Eisenach JH. Selective alpha2-adrenergic properties of dexmedetomidine over clonidine in the human forearm. J Appl Physiol. 2005;99:587-92

36. Beattie WS, Wijeysundera DN, Karkouti K, McCluskey S, Tait G, Mitsakakis N, et al. Acute surgical anemia influences the cardioprotective effects of $\beta$ blockade. Anesthesiology. 2010;112:25-33.

37. Holt J, Rhode $\mathrm{E}$, Kines $\mathrm{H}$. Ventricular volumes and body weight in mammals. Am J Physiol. 1968;215(3):704-15.

\section{Submit your next manuscript to BioMed Central and we will help you at every step:}

- We accept pre-submission inquiries

- Our selector tool helps you to find the most relevant journal

- We provide round the clock customer support

- Convenient online submission

- Thorough peer review

- Inclusion in PubMed and all major indexing services

- Maximum visibility for your research

Submit your manuscript at www.biomedcentral.com/submit 